\title{
Evaluation of the Potential of Organic Solvent Tolerant Bacillus sp. BCNU 5005
}

\author{
Hye Jung Choi ${ }^{1}$, Min Jung Hwang ${ }^{2}$, Young-Kee Jeong ${ }^{3}$ and Woo Hong Joo ${ }^{1,2} \star$ \\ ${ }^{1}$ Interdisciplinary Program in Biotechnology and ${ }^{2}$ Department of Biology, Changwon National University, Changwon 641-773, Korea \\ ${ }^{3}$ Department of Biotechnology, Dong-A University, Busan 604-714, Korea
}

Received February 4, 2011 /Accepted March 6, 2011

\begin{abstract}
Using enrichment procedures, we isolated organic solvent-tolerant Bacillus sp. BCNU 5005 from waste water and soil in the Ulsan industrial plant region. BCNU 5005 had a maximum similarity of $98 \%$ with $B$. subtilis and was designated as $B$. subtilis based on phylogenetic analyses using $16 \mathrm{~S}$ rDNA sequences. Generally, most bacteria and their enzymes are destroyed or inactivated in the presence of high concentrations of organic solvents. However, the lipase activity of B. subtilis BCNU 5005 was very stable in the presence of various kinds of solvents $(25 \%, \mathrm{v} / \mathrm{v})$ except chloroform, ethylbenzene and decane. Furthermore, BCNU 5005 was determined to have a degradative ability towards organic solvents. This organic solvent tolerant Bacillus sp. BCNU 5005 could be used as a new potential resource for biotransformation and bioremediation.
\end{abstract}

Key words : Bacillus sp. BCNU 5005, organic solvent tolerant bacteria, organic solvent tolerant lipase, degradative ability

\section{서 론}

방향족 화합물을 포함한 유기용매는 석유- 화학관련 산업, 농업, 생활 폐수 등에서 발생되는 주요 오염물질로 화학적 발 암성분들을 다수 포함하고 있어 인간에게 심각한 위협이 되고 있다. 이들 방향족 화합물을 포함하는 유기용매들은 물리·화 학적으로 안정하기 때문에 하천 및 토양 중에 유입되면 잘 분해되지 않고 환경에 축적되는 성질을 가지고 있어 고등생물 의 생식력을 감퇴시키고, 돌연변이와 기형을 유발하며 내분비 교란물질로 작용하여 생체 내 대사에 크게 영향을 미치는 것 으로 알려져 있다[1,3,17]. 그러므로 이들 물질의 생물학적 처 리는 인류의 생존에 필수적이다.

Toluene을 포함한 다양한 유기용매는 $0.1 \%(\mathrm{v} / \mathrm{v})$ 의 저농 도에서 대부분의 미생물 세포를 비롯한 모든 세포들을 구조 적-기능적으로 손상시킬 수 있는 강한 독성을 나타낸다. 그러나 1989년 이후로 고농도 유기용매에서 내성을 나타내 는 미생물들이 분리 보고되고 있으며 $[9,21]$, 현재는 이런 유 기용매 내성미생물의 산업적 활용도를 높이고자 하는 연구 가 활발히 이루어지고 있다. 다양한 종류의 고농도 유기용 매에 대해 내성을 가진 미생물은 방향족 화합물을 포함한 난분해성 물질을 분해하여 새로운 bioreactor로써 사용이 가 능하며 특히 환경공학, 발효공업 및 효소산업에서 중요한 역할을 할 것으로 기대된다.

현재 산업적으로 사용되고 있는 대부분의 효소는 수용액하 에서 사용되며 유기용매에 내성이 없는 효소이다. 용매로써의

*Corresponding author Tel : +82-55-213-3453, Fax : +82-55-213-3459

E-mail : whjoo@changwon.ac.kr
물은 가수분해, 아실기의 전이, 수산화이온의 친핵적 첨가 등 의 원하지 않는 부반응으로 인해 대부분의 화학적 변환에 있 어서 그다지 좋은 반응매체가 되지 못하며, 효소반응 대상인 지방, 오일, 방향족화합물, 스테로이드 등 많은 유기화합물은 수난용성이다[16]. 따라서 지용성 또는 수난용성 화합물의 생 화학적 변환에서 이러한 난점을 극복하고자 유기용매 하에서 의 효소반응에 대한 연구와 다양한 생체촉매의 탐색과 개발에 대한 연구가 현재 활발히 진행되고 있다[11,20]. 유기용매에서 의 효소반응으로 가장 많이 연구되고 있는 lipase는 수계에서 는 불가능한 transesterification, esterification, aminolysis, thiotransesterification 등의 반응을 촉매하며, 최근에는 lipase의 transesterificaion 기능을 이용한 새로운 ester 화합물의 합성 과 이들 물질을 합성하는데 있어서의 가장 유리한 유기용매계 의 선택 및 반응계의 제반조건 등에 대한 연구가 다양하게 행해지고 있다[8,12,22,24]. 현재 산업적으로 활용되고 있는 lipase 생성균주로는 Geotrichum sp., Penicillium sp., Aspergillus sp., Candida sp., Mucor sp., Rhizopus sp., Psudomanas sp. 등이 있으며, 그 중에서도 Psudomonas sp. 균주가 생산하는 lipase가 광범위하게 사용되고 있다[2,4,10,15,26]. 또한 유기용매 내성 효소의 탐색과 이용도 산업적으로 매우 중요한 과제로서 집중 적인 연구가 요구되고 있다.

따라서 본 연구에서는 울산공단 일대의 폐수 및 토양에서 유기용매 내성을 나타내는 균주를 분리하였고, 아직 보고가 미흡한 유기용매 내성 세균인 Bacillus sp. 균주에 대해 다양한 유기용매에 대한 내성 등 기본적인 조사를 실시하였다. 그리 고 그 유용성을 검증하기 위하여 온도, $\mathrm{pH}$, 금속이온, 유기용 매 등 여러 환경인자들이 lipase에 미치는 영향과 각종 물질의 분해능력을 조사함으로써 Bacillus sp. BCNU 5005 균주의 산 
업적인 이용 가능성에 대해 조사하여 보고하고자 한다.

\section{재료 및 방법}

\section{유기용매 내성 세균의 분리 및 lipase 생성 균주 선별}

유기용매 내성세균을 분리하기 위해 울산공단 일대의 폐수 및 토양을 채취하여 nutrient broth (NB) 등의 분리배지에 $10 \%$ (v/v) $n$-hexane을 첨가한 후 $25^{\circ} \mathrm{C}$ 에서 농화배양을 실시하였 다. $n$ Hexane에 대해 내성이 있는 균을 1 차 선별하였고, $10 \%$ toluene을 첨가하여 $25^{\circ} \mathrm{C}$ 에서 48 시간 동안 배양하여 toluene 에 내성이 뛰어난 균주를 2 차 선별하였다. 유기용매 내성균주 의 lipase 생산여부를 확인하기 위해서 기질인 $1 \%(\mathrm{w} / \mathrm{v})$ tributyrin이 첨가된 nutrient agar (NA) 배지 등 분리배지에 균을 접종하여 $37^{\circ} \mathrm{C}$ 에서 24-48시간 배양 후 투명환의 생성여부를 관찰하였다.

\section{생리, 생화학적 특성 및 형태학적 특성 조사}

유기용매 내성이 뛰어난 균주에 대해 Bergey's Manual of Determinative Bacteriology [18]에 준하여 생리, 생화학적 특 성을 조사하였고, 정확한 동정을 위하여 forward primer $\left(5^{\prime}\right.$ AGT TTG ATC CTG GCT CAG 3')와 reverse primer (5' ACG GCT ACC TTG TTA CGA CTT 3')를 사용하여 $16 \mathrm{~S}$ 리보좀 $\mathrm{DNA}$ 를 증폭하였으며 그 염기서열을 분석하였다. 나아가 염 기서열의 유사도를 조사하였고 계통수는 neighbor joining 법 과 bootstrap 분석에 의거하여 작성하였다.

\section{유기용매 내성 및 분해능 조사}

유기용매에 대한 내성 조사를 위해 균이 접종된 $\mathrm{NA}$ 평판배 지에 11 종의 다양한 유기용매를 overlay하여 $37^{\circ} \mathrm{C}$ 에서 $48-96$ 시간 동안 정치배양하였고, 유기용매에 대한 분해능 조사는 최소배지인 minimum salts medium (MSM; $0.715 \mathrm{~g} \mathrm{Na}_{2} \mathrm{HPO}_{4}$ - $2 \mathrm{H}_{2} \mathrm{O}, 0.365 \mathrm{~g} \mathrm{KH}_{2} \mathrm{PO}_{4}, 0.5 \mathrm{~g}\left(\mathrm{NH}_{4}\right)_{2} \mathrm{SO}_{4}, 0.1 \mathrm{~g} \mathrm{MgSO}_{4}$. $7 \mathrm{H}_{2} \mathrm{O}$, and $0.5 \%$ trace elements solution $\left(0.88 \mathrm{~g} \mathrm{Ca}\left(\mathrm{NO}_{3}\right)_{2}\right.$. $4 \mathrm{H}_{2} \mathrm{O}, 0.2 \mathrm{~g} \mathrm{FeSO} \cdot 7 \mathrm{H}_{2} \mathrm{O}, 0.01 \mathrm{~g} \mathrm{ZnSO}_{4} \cdot 7 \mathrm{H}_{2} \mathrm{O}, 0.01 \mathrm{~g}$ $\mathrm{H}_{3} \mathrm{BO}_{3}, 0.01 \mathrm{~g} \mathrm{CoSO}_{4} \cdot 7 \mathrm{H}_{2} \mathrm{O}, 0.01 \mathrm{~g} \mathrm{CuSO}_{4} \cdot 5 \mathrm{H}_{2} \mathrm{O}, 0.004 \mathrm{~g}$ $\mathrm{MnSO}_{4} \cdot \mathrm{H}_{2} \mathrm{O}, 0.004 \mathrm{~g} \mathrm{Ni}\left(\mathrm{NO}_{3}\right){ }_{26} 6 \mathrm{H}_{2} \mathrm{O}, 0.003 \mathrm{~g} \mathrm{Na}_{2} \mathrm{MoO}_{4} \cdot$ $\left.2 \mathrm{H}_{2} \mathrm{O}, 0.002 \mathrm{~g} \mathrm{Na}_{2} \mathrm{WO}_{4} \cdot 2 \mathrm{H}_{2} \mathrm{O}, 0.05 \mathrm{~N} \mathrm{H}_{2} \mathrm{SO}_{4}\right)$ )를 사용하였다. Duharm tube를 이용하여 다양한 유기용매 및 난분해성 물질 을 유일한 탄소원으로 첨가하였고 $37^{\circ} \mathrm{C}$ 에서 $48-96$ 시간 동안 정치배양한 뒤 생존유무로 분해능 여부를 확인하였다.

\section{조효소액 조제}

$\mathrm{NB}$ 배지에서 $37^{\circ} \mathrm{C}$ 에서 24 시간 진탕 배양하여 얻은 배양액 을 원심분리 $(10,000 \times \mathrm{g}, 15 \mathrm{~min})$ 한 후, 배양 상등액을 membrane filter $(0.22 \mu \mathrm{m})$ 로 여과 한 후 조효소액으로 사용하였다 [7].

\section{Lipase 활성도 측정}

Lipase의 활성은 기질인 pnitrophenyl palmitate ( $\mathrm{NNPP}$ )를 사용하여 측정하였다[25]. 즉, 조효소액에 $50 \mathrm{mM} p \mathrm{NPP} 10$ $\mu \mathrm{l}$ 과 $0.1 \mathrm{M}$ Tris- $\mathrm{HCl}$ 완충액 $(\mathrm{pH} 8) 0.9 \mathrm{ml}$ 을 첨가하여 $37^{\circ} \mathrm{C}$ 에 서 5분간 반응시킨 후 spectrophotometer를 이용하여 $410 \mathrm{~nm}$ 에서 흡광도를 측정하였다. 이때 조효소액을 첨가하지 않은 용액을 대조구로 사용하였다.

효소활성은 $\mathrm{pNPP}$ 로부터 1 분 동안 $1 \mu \mathrm{mol}$ 의 pnitrophenol $(p \mathrm{NP})$ 을 생산하는데 관여하는 효소의 양을 1 unit로 정의하였다.

\section{효소의 온도와 $\mathrm{pH}$ 안정성 조사}

조효소액의 온도 안정성을 조사하기 위하여 조효소액과 기 질, 완충액을 혼합한 효소혼합액을 $30,40,50,60,70^{\circ} \mathrm{C}$ 에서 1 시간 반응시킨 후 $410 \mathrm{~nm}$ 에서 잔존 효소 활성을 측정하였다. 또한 조효소액의 $\mathrm{pH}$ 안정성을 조사하기 위하여 $0.1 \mathrm{M}$ sodium acetate ( $\mathrm{pH} 4-5), 0.1 \mathrm{M}$ potassium phosphate ( $\mathrm{pH}$ 6-7), 그리 고 $0.1 \mathrm{M} \mathrm{Tris}-\mathrm{HCl}\left(\mathrm{pH}\right.$ 8-10) 완충액을 사용하여 $37^{\circ} \mathrm{C}$ 에서 24 시간 반응한 후 효소의 잔존 활성을 측정하였다. 양성 대조구 로 고정화 리파아제인 novozyme 435 (Novozyme, Denmark) 를 사용하여 효소의 안정성을 비교하였다.

\section{효소의 유기용매 안정성 조사}

유기용매에 대한 조효소액의 안정성은 benzene, toluene, xylene, $n$-hexane등 각종 유기용매를 사용하여 확인하였다 [19]. 조효소액에 $25 \%(\mathrm{v} / \mathrm{v})$ 농도의 유기용매를 첨가하여 $37^{\circ} \mathrm{C}$ 에서 $150 \mathrm{rpm}$ 으로 2시간 진탕 시킨 후 조효소액을 채취하여 잔존 효소활성을 측정하였다. 양성 대조구로 novozyme 435 를 사용하여 유기용매에 대한 효소의 안정성을 비교하였다.

\section{효소 활성에 대한 금속이온 영향 조사}

금속이온에 대한 효소활성도의 영향을 측정하기 위해 다양 한 금속이온 $\left(\mathrm{CaCl}_{2}, \mathrm{FeCl}_{3}, \mathrm{CuCl}_{2}, \mathrm{MgSO}_{4}, \mathrm{BaCl}_{2}, \mathrm{HgCl}_{2}, \mathrm{NiCl}_{2}\right.$ $\mathrm{ZnSO}_{4}, \mathrm{MnCl}_{2}, \mathrm{KCl}, \mathrm{NH}_{4} \mathrm{Cl}$ 및 $\mathrm{NaCl}$ )을 사용하여 확인하였다 [13]. 조효소액과 $1 \mathrm{mM}$ 의 금속이온을 $37^{\circ} \mathrm{C}$ 에서 1 시간 전반응 시키고 기질을 첨가하여 $37^{\circ} \mathrm{C}$ 에서 5 분간 반응 시킨 후 410 $\mathrm{nm}$ 에서 잔존 효소활성을 조사하였다.

\section{결 과}

\section{유기용매 내성세균 및 효소 생산 균주의 분리}

울산공단 일대의 폐수 및 토양시료에서 toluene에 내성을 가진 균주 10 여 종을 분리하였으며, 선별된 균주를 대상으로 tributyrin이 함유된 NA 배지에서 lipase 효소 생산여부를 확 인하였다. 고농도의 toluene이 포함된 환경에서 생장률이 뛰 어나며 lipase를 생산하는 균주를 선별하여 BCNU 5005로 명 명하여 본 실험에 사용하였다. 


\section{생리, 생화학적 특성 및 분자진화적 동정}

$\mathrm{BCNU} 5005$ 균주의 생리, 생화학적 특성을 조사한 결과, 그람양성으로 $25-70^{\circ} \mathrm{C}$ 에서 생육가능하였으며, $\mathrm{pH} 4$ 에서 9 까 지 넓은 $\mathrm{pH}$ 범위에서 생육가능함이 확인되었다. 또한 amylase, protease, lipase, urease 그리고 lecithinase를 생산하는 것으로 확인되었고(Table 1), $16 \mathrm{~S}$ 리보좀DNA 염기서열 분석 결과 Bacillus subtilis와 98\% 상동성을 가진 것으로 나타났으며 계통학적으로도 Bacillus subtilis 그룹에 속함이 확인되었다

(Fig. 1).

\section{Bacillus sp. BCNU 5005의 유기용매 내성 및 분해능}

유기용매의 독성을 나타내는 일반적인 지표로 사용되는 $\log$ Pow 값이 3.9-0.8 사이의 다양한 유기용매에 대한 내성을 조사한 결과, propylbenzne, $\sigma, m$, pxylene 그리고 toluene을 포함한 $\log$ Pow 값이 3.9-2.5 사이의 다양한 유기용매에 대해 내성을 나타내었다(Table 2). 또한 최소배지에 유기용매 및 난 분해성 물질을 첨가하여 균의 생존여부로 확인하는 분해능 실험 결과 anthracene, dibenzothiophene, naphthalene, nitrobenzene 그리고 toluene을 첨가했을 때 분해능이 우수함을 확 인할 수 있었다(Table 3).

\section{Lipase의 안정성 및 활성에 미치는 유기용매의 영향}

다양한 유기용매에 대한 효소의 안정성을 조사하기 위하여

Table 1. Physiologocal and biochemical characteristics of BCNU 5005

\begin{tabular}{ll}
\hline Characteristics & \\
\hline Gram reaction & + \\
Culture Characteristics & + \\
Growth temperature $\left(25-37^{\circ} \mathrm{C}\right)$ & + \\
Growth $\mathrm{pH}(4-9)$ & + \\
Growth $\mathrm{NaCl}(2-7 \%)$ & \\
Assimilation of & + \\
mannose & + \\
mannitol & + \\
fructose & - \\
lactose & + \\
glucose & - \\
galactose & \\
Production of & + \\
amylase & + \\
protease & + \\
lipase & + \\
gelatinase & + \\
catalase & - \\
urease & + \\
oxidase & - \\
lecithinase & - \\
methyl red reaction & \\
nitrate reduction test & - \\
\hline &
\end{tabular}

( +: postive, -: negatve)

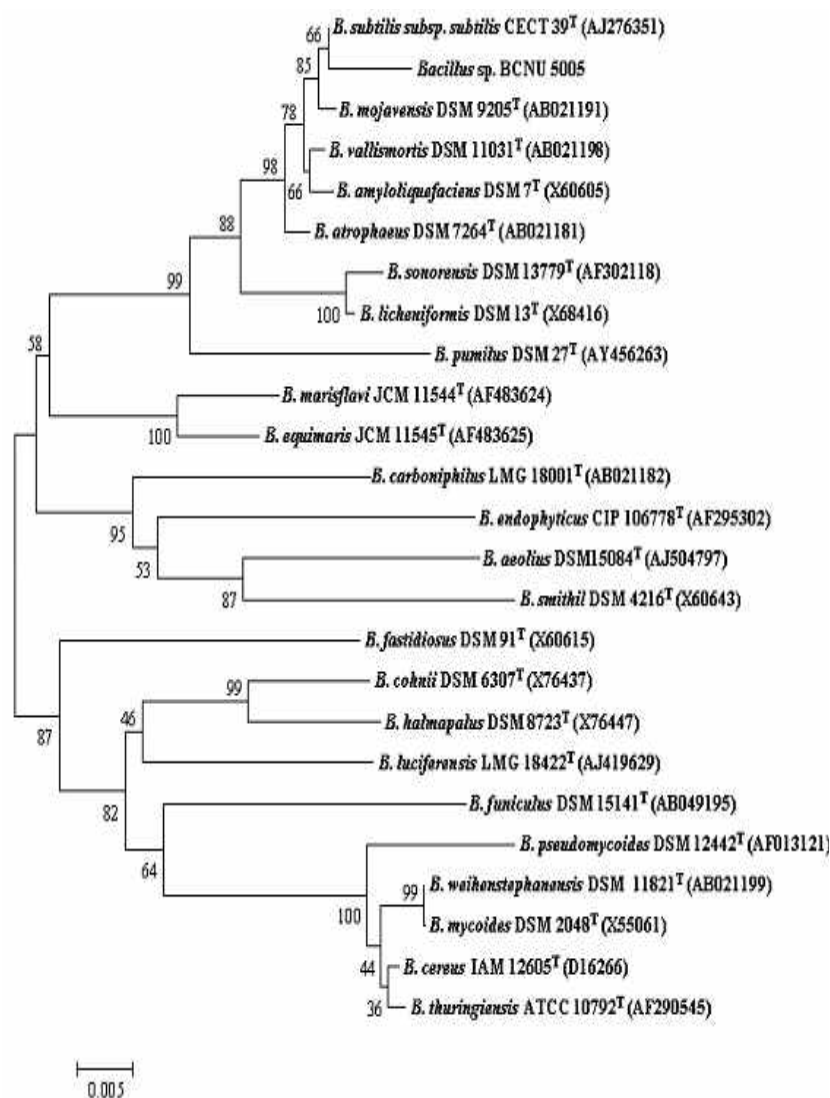

Fig. 1. A phylogenetic tree of the organic solvent-tolerant Bacillus sp. BCNU 5005 and closely related species.

Table 2. Organic solvent tolerance of Bacillus sp. BCNU 5005

\begin{tabular}{lcc}
\hline Solvent & log Pow & Bacillus sp. BCNU 5005 \\
\hline n-Hexane & 3.9 & + \\
Propylbenzene & 3.6 & + \\
Cyclohexane & 3.2 & + \\
oXylene & 3.1 & + \\
$m$-Xylene & 3.1 & + \\
pXylene & 3.1 & + \\
Toluene & 2.5 & + \\
Benzene & 2.0 & - \\
Chloroform & 2.0 & - \\
Phenol & 1.5 & - \\
$n$-Butanol & 0.8 & - \\
\hline
\end{tabular}

$25 \%$ 의 고농도 유기용매를 첨가한 뒤 효소의 잔존활성을 측정 하였다. 그 결과 toluene, cyclohexane, butanol 그리고 octane 을 첨가했을 때 각각 $140 \%, 108 \%, 111 \%, 128 \%$ 로 효소활성이 증가한 것으로 나타나 고정화 리파아제인 novozyme 435보다 Bacillus sp. BCNU 5005가 생산하는 lipase가 더 안정함을 알 수 있었다. 그러나 chloroform, ethylbenzene 및 hexane을 첨 가했을 때는 효소안정성이 다소 떨어지는 것으로 나타났다 (Fig. 2). 
Table 3. Biodegradative potential of Bacillus sp. BCNU 5005

\begin{tabular}{lc}
\hline Solvent & Bacillus sp. BCNU 5005 \\
\hline Anthracene & ++++ \\
Benzene & - \\
Benzene sulfornic acid & - \\
Dibenzothiophene & +++ \\
$p$ Dichlorobenzene & - \\
Diphenyl & - \\
Monochloroacetic cid & - \\
Naphthalene & ++++ \\
1-Naphthalene sulfornic acid & ++ \\
4-Nitrophenol & ++ \\
Nitrobenzene & ++++ \\
Pentachlorophenol & - \\
Phenanthrene & + \\
Phenolphthalein & +++ \\
Toluene & ++++ \\
\hline
\end{tabular}

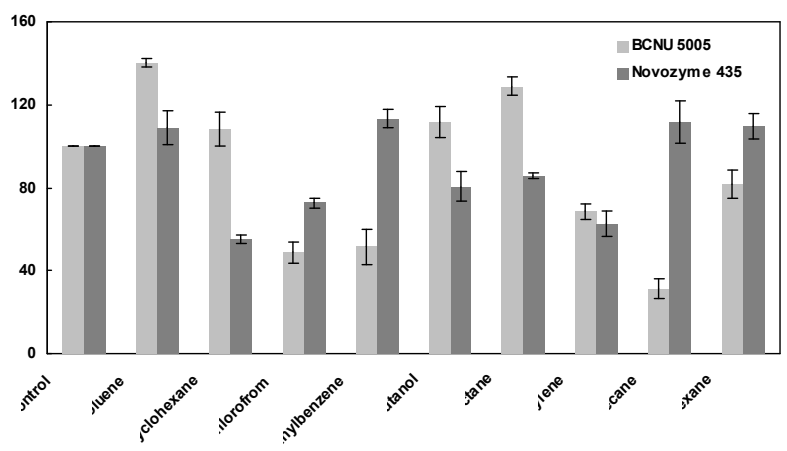

Fig. 2. Effect of organic solvent on the lipase stability. The lipase activity of the non-solvent containing control was taken as $100 \%$.

Bacillus sp. BCNU 5005가 생산하는 lipase 활성에 미 치는 온도의 영향

효소 활성에 미치는 온도의 영향을 조사하기 위해서 30-7 $0^{\circ} \mathrm{C}$ 까지의 넓은 온도 범위에서 실험한 결과, $37^{\circ} \mathrm{C}$ 에서 가장 높은 활성을 나타내었고, $30^{\circ} \mathrm{C}$ 와 $50^{\circ} \mathrm{C}$ 에서도 각각 잔존활성이 $53 \%, 71 \%$ 로 비교적 높은 효소활성을 유지함이 조사되었다 (Fig. 3).

\section{Lipase 활성에 미치는 $\mathrm{pH}$ 의 영향}

$\mathrm{pH}$ 변화에 따른 lipase 활성을 조사하기 위해 다양한 $\mathrm{pH}$ 범위의 완충액을 사용하여 측정한 결과 Bacillus sp. BCNU 5005 는 $\mathrm{pH}$ 8에서 가장 높은 활성을 나타냈고, $\mathrm{pH}$ 5-7에서 $80 \%$ 이상의 높은 효소활성을 보였으며, $\mathrm{pH} 4$ 에서도 $70 \%$ 정도 의 효소 활성을 나타내었다(Fig. 4).

Lipase 활성에 미치는 금속이온의 영향

다양한 금속이온을 첨가하여 효소 활성에 미치는 영향을

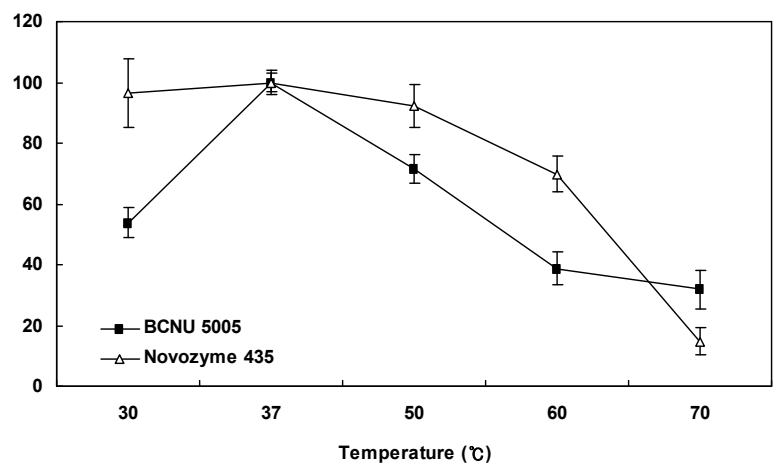

Fig. 3. Effect of temperature on lipase activity. The diluted cell-free supernatant was incubated with the substrate at different temperatures. The activity $(7.39 \mathrm{U} / \mathrm{ml})$ at $37^{\circ} \mathrm{C}$ was taken as $100 \%$.

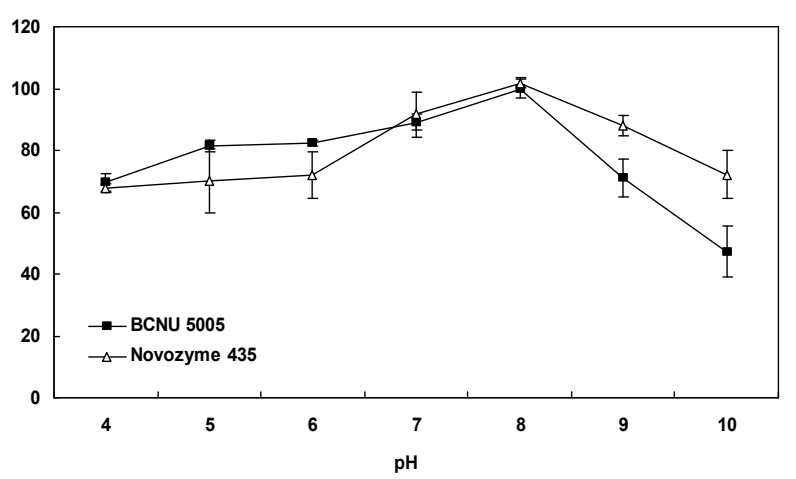

Fig. 4. Effect of $\mathrm{pH}$ on the lipase stability. The remained activity was measured by incubating enzyme with the substrate at different $\mathrm{pH}$ values.

Table 4. Effect of metal ions on the lipase activity of BCNU 5005

\begin{tabular}{lc}
\hline & Relative activity $(\%)$ \\
\hline None & 100 \\
$\mathrm{CaCl}_{2}$ & 79.16 \\
$\mathrm{CuCl}_{2}$ & 117.02 \\
$\mathrm{FeCl}_{3}$ & 113.43 \\
$\mathrm{MgSO}_{4}$ & 109.24 \\
$\mathrm{BaCl}_{2}$ & 75.13 \\
$\mathrm{HgCl}_{2}$ & 89.91 \\
$\mathrm{NiCl}_{2}$ & 63.74 \\
$\mathrm{ZnSO}_{4}$ & 61.68 \\
$\mathrm{MnCl}_{2}$ & 47.88 \\
$\mathrm{KCl}$ & 104.06 \\
$\mathrm{NH}$ & 117.19 \\
$\mathrm{NaCl}$ & 83.64 \\
\hline
\end{tabular}

측정한 결과, $\mathrm{CuCl}_{2}, \mathrm{FeCl}_{3}, \mathrm{MgSO}_{4}, \mathrm{KCl}$ 그리고 $\mathrm{NH}_{4} \mathrm{Cl}$ 를 첨가 했을 때 1-1.2배 높은 활성을 보였으며, $\mathrm{CaCl}_{2}, \mathrm{HgCl}_{2}, \mathrm{ZnSO}_{4}$ 등을 첨가했을 때는 효소활성이 저해를 받는 것으로 나타났 
다. 특히 $\mathrm{MnCl}_{2}$ 에 의해 lipase의 활성이 가장 떨어지는 것으로 나타났다(Table 4).

\section{고 찰}

산업적으로 유기용매에 내성을 가지는 미생물과 그 효소에 의한 생물전환 및 생물복구에 대한 기술개발이 꾸준히 요구됨 에 따라 고농도의 유기용매에서 생육할 수 있는 미생물의 탐 색과 기능해석 및 산업적 응용 개발을 위한 연구가 활발히 진행되고 있다. 현재 유기합성 공업에는 주로 미생물이나 동 물기원의 효소가 이용되고 있으며, 이들 미생물들은 유기용매 내에서 생존이 어렵거나 사멸하므로 고정화시키는 것이 일반 적이다. 그러나 유기용매 내성세균으로 대체하면 이러한 고정 화 비용 및 효소 사용비용을 절감할 수 있고 균주의 회수와 재이용이 가능하므로 유기용매 내성 세균과 그 효소는 새로운 생체촉매로서 높은 이용가치를 갖는다.

본 연구에서는 울산공단 일대의 폐수 및 토양에서 유기용매 내성 세균을 새롭게 분리하였으며, Bacillus sp. BCNU 5005의 난분해성 물질의 분해능력과 생산하는 lipase의 여러 가지 효 소학적 특성에 대해 조사하였다. 균주가 생산하는 lipase는 고 정화 리파아제인 novozyme 435 와 비교했을 때 유의하게 $37^{\circ} \mathrm{C}$, $\mathrm{pH}$ 8에서 가장 높은 활성을 나타내었고, 온도 $30-50{ }^{\circ} \mathrm{C}, \mathrm{pH}$ $4-7,9$ 범위에서도 최고활성의 $70 \%$ 이상의 활성이 있는 것으로 나타났다. Bacillus sp. RN2는 $45^{\circ} \mathrm{C}, \mathrm{pH}$ 9가 최적조건이나 효소 활성은 약 $60 \%$ 로 나타났으며[14], Bacillus cereus C71과 Pseudomonas sp. M-37은 각각 $33^{\circ} \mathrm{C}, \mathrm{pH} 9,55^{\circ} \mathrm{C}, \mathrm{pH}$ 9에서 높은 활성을 나타냈으나, 그 외 조건에서 효소활성이 급격히 떨어지는 것으로 보고되었다[5,23]. 이에 비하여 Bacillus sp. $\mathrm{BCNU} 5005$ 가 생산하는 lipase는 비교적 넓은 온도와 $\mathrm{pH}$ 범위 에서도 효소 안정성이 있음이 확인되었다. BCNU 5005 균주는 hexane, propylbenzene, xylene 및 toluene을 포함한 다양한 유기용매에 대해 내성을 나타내었으며, 특히 독성이 강한 toluene에서는 빠른 생육속도를 보였다. 또한 anthracene, dibenzothiophene, naphthalene, 1-naphthalene sulfornic acid, 4-nitrophenol 및 nitrobenzene 등 다양한 난분해성 물질을 분 해하는 것으로 확인되었다.

각종 금속이온에 대한 영향은 $\mathrm{CuCl}_{2}, \mathrm{FeCl}_{3}, \mathrm{MgSO}_{4}, \mathrm{KCl}$, $\mathrm{NH}_{4} \mathrm{Cl}$ 를 첨가했을 때 대조군에 비해 1-1.2배 높은 효소활성을 나타내어 대부분의 금속이온에 크게 영향을 받지 않는 것으로 조사되었다. Bacillus sp. RN2는 연구에서 $\mathrm{KCl}, \mathrm{CuCl}_{2}, \mathrm{ZnCl}_{2}$ 를 첨가했을 때 효소활성이 증가했으나, 대부분의 금속이온이 대 조군에 비해 활성이 다소 떨어진다고 보고한 바 있다[14]. 또한 butanol, cyclohexane, toluene 그리고 octane을 첨가했을 때 효소활성이 $100 \%$ 이상으로 고농도의 유기용매하에서도 안정 성이 뛰어났다. B. sphaericus는 정제된 lipase의 경우 n-butanol 과 toluene을 첨가했을 때 효소 안정성이 각각 $23 \%, 40 \%$ 로
떨어졌으며[23], 대부분의 유기용매에 대해 효소활성이 떨어 진 Staphylococcus saprophyticus와 비교했을 때[6] BCNU 5005 는 선택적으로 대조군에 비해 효소 활성이 뛰어남을 확인할 수 있었다.

유기용매 내성 lipase를 생산하는 Bacillus sp. BCNU 5005는 비교적 넓은 온도와 $\mathrm{pH}$ 범위, 다양한 유기용매 및 금속이온 하에서 안정한 효소활성을 가졌으며, 현재 산업적으로 사용하 고 있는 고정화 리파아제인 novozyme 435와 비교했을 때도 비교적 안정한 효소활성을 가진 것을 알 수 있었다. 또한 일부 유기용매 하에서는 Bacillus sp. BCNU 5005가 생산하는 lipase 가 고정화된 효소보다 더 안정함을 확인할 수 있었다. 따라서 지속적인 연구를 통해 미생물을 이용한 생분해 등 환경산업 분야와 생물전환반응 등 화학산업분야를 포함한 고부가가치 의 산업기술 분야에 유용하게 적용될 수 있을 것으로 크게 기대된다.

\section{감사의 글}

본 연구는 한국연구재단 기본연구지원사업(과제번호: 2010-0009141)에 의해 지원되었으므로 이에 감사드립니다.

\section{References}

1. Abe, A., A. Inoue, R. Usami, K. Moriya, and K. Horikoshi. 1995. Degration of polyaromatic hydrocarbons by organic solvent tolerant bacteria from Deep Sea. Biosci. Biotech Biochem 59, 1154-1156.

2. Aono, R., M. Itoh, A. Inoue, and K. Horikoshi. 1992. Isolation of novel toluene-tolerant strain Pseudomonas aeruginosa. Biosci. Biotechnol. Biochem 56, 145-146.

3. Bouchez, M., D. Blanchet, and J. P. Vandecasteele. 1996. The microbiological fate of polycyclic aromatic hydrocarbons: carbon and oxygen balances for bacterial degradation of model compounds. Appl. Microbiol. Biotechnol. 45, 556-561.

4. Cruden, D. L., J. H. Wolfram, R. D. Rogers, and D. T. Gibson. 1992. Physiological properties of a Pseudomonas strain which grows with $p$ xylene in two phase (organic-aqueous) medium. Appl. Environ. Microbiol. 58, 2723-2729.

5. Dahiya, P., P. Arora, A. Chaudhury, S. Chand, and N. Dilbaghi. 2010. Charaterization of an extracellular alkaline lipase from Pseudomonas mendocina M-37. J. Basic Microbiol. 50, 420-426.

6. Fang, Y., Z. Lu, F. Lv, X. Bie, S. Liu, Z. Ding, and W. Xu. 2006. A newly isolated organic solvent tolerant Staphylococcus saprophyticus M36 produced organic solvent stable lipase. Curr. Microbiol. 53, 510-515.

7. Gaur, R., A. Gupta, and S. K. Khare. 2008. Lipase from solvent tolerant Pseudomonas aeruginosa strain: production optimization by response surface methodology and application. Bioresour. Thehnol. 99, 4796-4802.

8. Hasan, F., A. A. Shah, and A. Hameed. 2006. Industrial ap- 
plications of microbial lipase. Enzyme Microb. Technol. 39, 235-251.

9. Inoue, A. and K. Horikoshi. 1989. A Pseudomonas putida thrives in high cincentrations of toluene. Nature 338, 264-266.

10. IWai, M. and Y. Tsujisaka. 1974. The purification and properites of three kinds of lipase from Rhizopus deleman. Arg. Biol. Chem 38, 1241-1247.

11. Jaeger, K. E., B. W. Dijkstra, and M. T. Reetz. 1999. Bacterial biocatalysts: molecular biology, three-dimensional structures and biotechnological applications of lipases. Annu. Rev. Microbiol. 53, 315-351.

12. Jaeger, K. E. and T. Eggert. 2004. Enantioselective biocatalysis optimized by directed evolution. Curr. Opin. Chem Biol. 15, 305-313.

13. Ji, Q., S. Xiao, B. He, and X. Liu. 2010. Purification and characterization of an organic solvent-tolerant lipase from Pseudomonas aeruginosa LK1 and its application ofr biodiesel production. J. Mol. Catal. B: Enzyme. 66, 264-269.

14. Kanjanavas, P., S. Khuchareontaworn, P. Khawsak, A. Pakpitcharoen, K. Pothivejkul, S. Santiwatanakul, K. Matsui. T. Kajiwara, and K. Chansiri. 2010. Purification and characterization of organic solvent and detergent tolerant lipase from thermotolerant Bacillus sp. RN2. Int. J. Mol. Sci. 11, 3783-3792.

15. Kawase, M. and A. Tanaka. 1989. Effects of chemical modification of amino acid residues on the activities of lipase from Candida cylindracea, Enzyme Microb. Technol. 11, 44-48.

16. Kodera, Y., H. Nishumura, A. Matsushima, M. Hiroto, and Y. Inada. 1994. Lipase made active in hydrophobic media by coupling with polyethylene glycol. J. Am Oil Chem Soc. $71,335-338$.

17. Lee. S. K. and S. B. Lee. 2001. Isolation and characterization of a thermotolerant bacterium Ralstonia sp. strain PHS1 that degrades benzene, toluene, ethylbenzene, and oxylene.
Appl. Microbiol. Biotechnol. 61, 1-12.

18. Locci, R. 1989. Streptomycetes and related genera, pp. 2451-2492, In Williams, S. T., M. E. Sharpe, and J. G. Holt (eds.). Bergey's Manual of systematic bacteriology, 9th, Vol. 4, Williams \& Willikins, Baltimore.

19. Ogino, H., K. Miyamoto, M. Yasuda, K. Ishimi, and H. Ishikawa. 1999. Growth of organic solvent-tolerant Pseudomonas aeruginosa LST-03 in the presence of various organic solvents and production of lipolytic enzyme in the presence of cyclohexane. Biochem Eng. J. 4, 1-6.

20. Pandey, A., S. Benjamin, C. R. Soccol, P. Nigam, N. Krieger, and U. T. Soccol. 1999. The realm of microbial lipases in biotechnology. Biotechnol. Appl. Biochem 29, 119-131.

21. Pinkart, H. C., J. W. Wolfram, R. Rogers, and D. C. White. 1996. Cell envelope changes in solvent-tolerant and solvent sensitive Pseudomonas putida strains following exposure to o-xylene. Appl. Environ. Microbiol. 62, 1129-1132.

22. Polizzi, K. M., A. S. Bommarius, J. M. Broering, and J. F. Chaparro-Riggers. 2007. Stability of biocatalysts. Curr. Opin. Chem Biol. 11, 220-225.

23. Shaoxin, C., Q. Lilia, and S. Bingzhao. 2007. Purification and properties of enantioselective lipase from a newly isolated Bacillus cereus C71. Process Biochem 42, 988-994.

24. Sulong, M. R., R. N. Abdul Rahman, A. B. Salleh, and M. Basri. 2006. A novel organic solvent tolerant lipase from Bacillus sphaericus 205y: Extracellular expression of a novel OST-lipase gene. Pro. Exp. Puri. 49, 190-195.

25. Winkler, U. K., A Gupta, and M. Stuckmann. 1979. Glycoen, hyalurinate, and some other polysaccharides greatly enhance the formation of exolipase by Serratua narcescens. J. Bacteriol. 138, 663-670.

26. Yamada, K. and H. Machida. 1962. Studies on the production of lipases by microorganisms, I / II., Nippon Nogei Kagaku Kaishi. 36, 858-864.

\section{초록 : 유기용매내성 세균 Bacillus sp. BCNU 5005의 유용성에 대한 검증}

최혜정 ${ }^{*}$ 황민정 ${ }^{2} \cdot$ 정영기 $^{3} \cdot$ 주우홍 ${ }^{12} \star$

(창원대학교 생물공학협동과정, ${ }^{2}$ 창원대학교 생물학과, ${ }^{3}$ 동아대학교 생명공학과)

농화배양법을 이용하여 울산공단 일 대의 폐수 및 토양에서 유기용매 내성 Bacillus sp. BCNU 5005를 분리하였 다. $16 \mathrm{~S}$ 리보좀DNA 염기서열 분석결과 BCNU 5005 균주는 B. subtilis와 $98 \%$ 상동성을 가진 것으로 나타났으며 계통학적으로도 B. subtilis임이 확인되었다. 일반적으로 대부분의 세균과 그들의 효소는 고농도 유기용매하에서 불활성화되거나 파괴된다. 그러나. Bacillus sp. BCNU 5005의 lipase 활성은 chloroform, ethylbenzene 그리고 decane을 제외한 다양한 종류의 유기용매 $(25 \%, \mathrm{v} / \mathrm{v})$ 에서 매우 안정함을 보였다. 게다가 $\mathrm{BCNU} 5005$ 는 유기용매 를 분해하는 능력을 가진 것으로 확인하였다. 유기용매 내성 Bacillus sp. BCNU 5005는 생물전환과 생물복구산업 을 위한 새로운 잠재적인 자원으로서 이용될 수 있다. 